\title{
INSTYTUCJONALNE, ŚWIATOPOGLĄDOWE OTOCZENIE ADMINISTRACJI PUBLICZNEJ A JEJ TAK ZWANA APOLITYCZNOŚĆ
}

\begin{abstract}
Abstrakt: Administracja publiczna to szczególny rodzaj organizacji. Działa w określonym otoczeniu. Jego szczególnymi elementami są partie polityczne oraz kościoły i związki wyznaniowe. Administracja publiczna powinna realizować zadania publiczne, kierując się interesem publicznym. Powinna być neutralna ideologicznie i światopoglądowo.
\end{abstract}

Słowa kluczowe: administracja publiczna, organizacja, otoczenie, interes publiczny, neutralność ideologiczna, neutralność światopoglądowa

\section{WSTĘP}

Administrację publiczną można wielorako ujmować, eksponując różne jej aspekty: przedmiotowo-podmiotowy, funkcjonalny, organiczny. Przykładem pierwszego z nich jest definicja Huberta Izdebskiego i Michała Kuleszy, według której „Przez administrację publiczną rozumie się zespół działań, czynności i przedsięwzięć organizatorskich i wykonawczych, prowadzonych na rzecz realizacji interesu publicznego przez różne podmioty, organy i instytucje, na podstawie ustawy i w określonych prawem formach"1. Ujęcie drugie to bez wątpienia koncepcja Franciszka Longchamps administracji publicznej jako zjawiska będącego działaniem kulturowym na stanowisku publicznym, objętym podziałem pracy ${ }^{2}$. Trzecią propozycję sformułował Jerzy S. Langrod, przyjmując, że administracja

to ludzie zorganizowani po to, aby korzystając z przydzielonej im dziedziny aktywności (sfery działania) i z rozporządzalnych rzeczy (środków działania), mogli spełniać swoje zadanie. Czy ujmiemy ich łącznie w ramy teoretyczne konstrukcji służby publicznej, czy inaczej — zawsze będzie to przede

1 H. Izdebski, M. Kulesza, Administracja publiczna. Zagadnienia ogólne, Warszawa 2004, s. 93.

2 F. Longchamps, Założenia nauki administracji, Wrocław 1993, s. 89. 
wszystkim planowe zgrupowanie ludzi w służbie pewnej misji publicznej, a dopiero potem — poprzez tych ludzi — suma urządzeń, którymi oni dysponują ${ }^{3}$.

\section{ADMINISTRACJA PUBLICZNA W UJĘCIU NAUK ORGANIZACYJNYCH}

Nietrudno chyba zauważyć, że to ostatnie ujęcie ujmuje administrację, także publiczną, w sposób zbliżony, jeśli nie identyczny, do jednego z podstawowych pojęć nauki organizacji i zarządzania, organizacji i instytucji. Związek ten podkreślił zresztą sam Langrod, wskazując, w kontekście swojej definicji, że:

Taki układ pojęć, w którym punktem wyjścia jest zawsze człowiek — choć ujęty w ramy przemyślanego systemu organizacyjnego - a przedmiot, urządzenie, instrument stanowi element wtórny — jest doniosłym wskaźnikiem prowadzącym do zrozumienia poszczególnych problemów w nauce prawa administracyjnego [w nauce administracji także a może i przede wszystkim - A.P.] i ich wzajemnej symetrii. Jest to właśnie najważniejszy punkt styczny nauki administracji [sic! A.P.] z nauką o gestii przedsiębiorstw (administracją przemysłową).

To organizacyjne, czy też jak Langrod określał „organiczne”, ujęcie stanowi punkt wyjścia do dalszych rozważań ${ }^{4}$.

W prakseologicznym ujęciu Jana Zieleniewskiego instytucja ,to rzecz zorganizowana, złożona z ludzi połączonych jakąś wiązką wspólnych celów wraz z zasobami, których ludzie ci używają w swym działaniu"5. Podobnie do tej kwestii podchodzą inni przedstawiciele nauki organizacji i zrządzania, także z grona niewyróżniających instytucji jako szczególnego rodzaju organizacji, ściślej utożsamiających te pojęcia. Tytułem przykładu, według Andrzeja K. Koźmińskiego:

Organizacja - w znaczeniu rzeczowym - [jest to - A.P.] obiekt, który charakteryzuje się współprzyczynianiem się części do powodzenia całości i całości do powodzenia części, w znaczeniu atrybutowym stopniowalna cecha przedmiotów złożonych zwana zorganizowaniem, w znaczeniu czynnościowym tworzenie organizacji zwane organizowaniem ${ }^{6}$.

Zdaniem Ricky’ego W. Griffina organizację tworzy „Grupa ludzi, którzy współpracują ze sobą w sposób uporządkowany i skoordynowany, aby osiągnąć pewien zestaw celów"7. Z kolei James A.F. Stoner, R. Edward Freeman i Daniel R. Gilbert jr. przyjmują, że organizacja to „dwie lub więcej osób, współpracujących $\mathrm{w}$ ramach określonej struktury stosunków, aby osiągnąć określony cel lub

3 J.S. Langrod, Instytucje prawa administracyjnego. Zarys części ogólnej, Kraków 2003, (reprint), s. 228.

4 Ibidem.

5 J. Zieleniewski, Organizacja i zarzadzanie, Warszawa 1981, s. 279.

${ }^{6}$ A.K. Koźmiński, Organizacja, [w:] A.K. Koźmiński, W. Piotrowski, Zarządzanie. Teoria i praktyka, Warszawa 2002, s. 42. Autor ten przyjmuje ogólne prakseologiczne rozumienie organizacji. Zob. J. Zieleniewski, op. cit., s. 265-267.

7 R.W. Griffin, Podstawy zarzadzania organizacjami, Warszawa 1996, s. 35. 
zbiór celów"8. Ujmowanie administracji jako organizacji czy też jej szczególnej postaci - instytucji w żadnym stopniu nie podważa prawnoustrojowego charakteru administracji publicznej w demokratycznym państwie prawnym jako wykonawczej funkcji władzy publicznej, jedynie zaś stwarza możliwość wskazania na inne aspekty jej funkcjonowania, $\mathrm{z}$ wykorzystaniem dorobku stosownych nauk wspomagających, co jest przecież charakterystyczne dla badań prowadzonych na gruncie nauki administracji. Jednym z takich właśnie aspektów jest otoczenie administracji publicznej.

\section{KONCEPCJA OTOCZENIA ORGANIZACJI W ODNIESIENIU DO ADMINISTRACJI PUBLICZNEJ}

Każda organizacja czy instytucja funkcjonuje w konkretnej przestrzeni, określanej ogólnie mianem otoczenia stanowiącego, według jednego z określeń, „wszystkie elementy znajdujące się poza organizacją, mające związek z jej funkcjonowaniem, w tym elementy o bezpośrednim i pośrednim oddziaływaniu, zwane też środowiskiem zewnętrznym"9.

W literaturze przedmiotu wskazuje się przy tym na złożoność otoczenia. Andrzej K. Koźmiński wyróżnia otoczenie organizacji, otoczenie ogólne i otoczenie międzynarodowe i globalne ${ }^{10}$. Otoczenie organizacji zawiera wszystkie elementy niebędące częścią organizacji i oddziałujące na nią bezpośrednio i pośrednio. Otoczenie ogólne z kolei stwarza warunki funkcjonowania organizacji, a w jego skład wchodzą, między innymi, system prawny, system polityczny, system ekonomiczny, środowisko naturalne, system społeczny, kultura. Otoczenie międzynarodowe i globalne natomiast tworzą te elementy otoczenia ogólnego organizacji, które ujawniają się w skali międzynarodowej i globalnej.

Bardziej rozbudowaną koncepcję wymiarów otoczenia formułuje Ricky W. Griffin. Przede wszystkim autor ten wyróżnia otoczenie zewnętrzne, w którego skład wchodzą wszystkie elementy usytuowane poza organizacją, mogące na nią oddziaływać, i otoczenie wewnętrzne, określone jako siły i warunki występujące wewnątrz organizacji. Następnie w ramach otoczenia zewnętrznego wydzielone zostaje otoczenie ogólne i otoczenie celowe ${ }^{11}$.

Otoczenie ogólne „To niesprecyzowane bliżej wymiary i siły, wśród których działa organizacja i które mogą mieć wpływ na jej działania”, otoczenie celowe zaś to już „Konkretne organizacje lub grupy, które mogą wpływać na organizację"12.

\footnotetext{
8 J.A.F. Stoner, R.E. Freeman, D.R. Gilbert jr., Kierowanie, Warszawa 2001, s. 20.

9 Ibidem, s. 619.

10 A.K. Koźmiński, op. cit., s. 42.

11 Ibidem, s. 104.

12 Ibidem.
} 
Otoczenie ogólne ma kilka wymiarów, mianowicie ekonomiczny (ogólny stan systemu gospodarczego), techniczny (technologie i metody umożliwiające przekształcanie zasobów w towary i usługi), socjokulturowy (składają się nań wartości, zwyczaje, przyzwyczajenia, cechy demograficzne, cechy psychospołeczne, postawy), prawno-polityczny (system prawny, relacje między państwem a organizacjami), międzynarodowy (stopień uczestnictwa organizacji na forum międzynarodowym i uzależnienia organizacji od podmiotów międzynarodowych $)^{13}$. Otoczenie celowe natomiast to konkurenci, klienci, dostawcy, regulatorzy (podmioty mogące w różny sposób oddziaływać, głównie przez regulację, na politykę i praktyki organizacji, agencje regulacyjne, grupy interesu, siła robocza, właściciele, sojusznicy strategiczni ${ }^{14}$. W innym jeszcze ujęciu otoczenie organizacji ujmuje się w kategorii interesariuszy, za których uważa się zarówno jednostki, jak i grupy zainteresowane powodzeniem organizacji, którzy mogą wywierać wpływ na decyzje organizacji lub być od tych decyzji uzależnionymi ${ }^{15}$. Wydaje się jednak, że najbardziej trafną koncepcją ujmowania otoczenia jest ujęcie prakseologiczne, wyróżniające rdzeń, krąg zewnętrzny i otoczenie organizacji (instytucji), zaproponowane przez Jana Zieleniewskiego ${ }^{16}$.

Rdzeń tworzą członkowie danej organizacji, najbardziej trwale z nią związani (stosunkiem pracy lub członkostwem formalnie potwierdzonym), z tytułu czego pobierają stosowne wynagrodzenie, którzy swoimi działaniami bezpośrednio współprzyczyniają się do powodzenia organizacji. Takie ujęcie bez wątpienia jest bardziej właściwe i logicznie, i językowo niż Griffinowskie otoczenie wewnętrzne. Do kręgu zewnętrznego zaliczani są natomiast ci uczestnicy danej organizacji, którzy są niezbędni do jej funkcjonowania (klienci, dostawcy, usługobiorcy, bez których realizacja celu organizacji nie byłaby możliwa. Nie są oni jednak trwale z organizacją związani, nie pobierają też żadnego wynagrodzenia, a niekiedy muszą ponosić z tytułu uczestnictwa pewne koszty. Do kręgu zewnętrznego należy, jak sądzę, zaliczyć także podmioty oddziałujące na politykę i funkcjonowanie organizacji (podmioty nadzorujące, kontrolne, regulujące). Można zatem przyjąć, że kręgowi zewnętrznemu odpowiada otoczenie celowe w rozumieniu R.W. Griffina. Otoczenie wreszcie to wszyscy pozostali, w zasadzie bez powiązań z daną organizacją, a tym samym niebędący niezbędnymi w takim stopniu jak elementy rdzenia czy kręgu zewnętrznego do istnienia danej organizacji. Odpowiada to w pewnym stopniu pojęciu otoczenia ogólnego R.W. Griffina.

Administracja publiczna jako organizacja ma oczywiście swój krąg zewnętrzny czy też otoczenie celowe. Bez wątpienia należą do niego interesanci, różnego rodzaju podmioty zbiorowe, pozostałe organy władzy publicznej. Wydaje się, że

13 Ibidem, s. 104-108.

14 Ibidem, s. 108-115.

15 H. Steinmann, G. Schreyogg, Podstawy kierowania przedsiębiorstwem. Koncepcje, funkcje, przyktady, Wrocław 1992, s. 38.

16 J. Zieleniewski, op. cit., s. 303-313. 
warto bliżej przyjrzeć się tym drugim — podmiotom zbiorowym, przede wszystkim bez wątpienia szczególnym organizacjom (instytucjom) światopoglądowym, a to $\mathrm{z}$ racji przedmiotu i podstawowego celu działania administracji w demokratycznym państwie prawnym. Organizacje te to partie polityczne oraz kościoły i związki wyznaniowe.

\section{PARTIE POLITYCZNE JAKO PODMIOTY ZBIOROWE OTOCZENIA ADMINISTRACJI PUBLICZNEJ}

W myśl art. 11 ust. 1 Konstytucji Rzeczypospolitej Polskiej ${ }^{17}$ Rzeczpospolita Polska zapewnia wolność tworzenia i działania partii politycznych. Partie polityczne zrzeszają na zasadach dobrowolności i równości obywateli polskich w celu wpływania metodami demokratycznymi na kształtowanie polityki państwa. Konstytucja jednocześnie, $w$ art. 13, zakazuje istnienia partii politycznych i innych organizacji odwołujących się w swoich programach do totalitarnych metod i praktyk działania nazizmu, faszyzmu i komunizmu, a także tych, których program lub działalność zakłada lub dopuszcza nienawiść rasową i narodowościową, stosowanie przemocy w celu zdobycia władzy lub wpływu na politykę państwa albo przewiduje utajnienie struktur lub członkostwa.

Konstytucyjna regulacja, siłą rzeczy ogólna, znajduje rozwinięcie w ustawie z dnia 27 czerwca 1997 roku o partiach politycznych ${ }^{18}$. W art. 1 ust. 1 tej ustawy nieco precyzyjnej zdefiniowano partię polityczną, określając, że jest dobrowolną organizacją, występującą pod określoną nazwą, stawiającą sobie za cel udział w życiu publicznym przez wywieranie metodami demokratycznymi wpływu na kształtowanie polityki państwa lub sprawowanie władzy publicznej. Ustawa wyznacza jednocześnie, w art. 5, granice działalności partii politycznych, wskazując, że nie mogą one wykonywać zadań zastrzeżonych w przepisach prawa dla organów władzy publicznej ani zastępować tych organów w wykonywaniu ich zadań. Niedozwolone jest także, na mocy art. 7 ustawy, istnienie jednostek organizacyjnych partii politycznych w zakładach pracy.

Nie ulega wątpliwości, że główną przestrzenią aktywności partii politycznych jest udział w wyborach parlamentarnych i samorządowych, a w konsekwencji bezpośredni wpływ na skład personalny parlamentu i organów stanowiących jednostek samorządu terytorialnego, a w dalszej kolejności na skład personalny rządu i organów wykonawczych jednostek samorządu terytorialnego. Partie polityczne jawią się zatem jako podstawowe elementy kręgu zewnętrznego administracji publicznej, a biorąc po uwagę partyjną zasadniczo proweniencję rządu i organów

17 Konstytucja Rzeczypospolitej Polskiej z dnia 2 kwietnia 1997 roku (Dz.U. Nr 78, poz. 483 ze sprost. i późn. zm., dalej: Konstytucja).

18 Dz.U. z 2017 r. poz. 876. 
wykonawczych jednostek samorządu terytorialnego, przenikają, przez swoich członków i sympatyków, do samego rdzenia administracji publicznej.

W demokratycznym państwie prawnym administracja publiczna, to, od strony przedmiotowej, wykonywanie określonych prawem zadań publicznych w celu realizacji interesu publicznego. Administracja publiczna to służba państwu i społeczeństwu. Powstaje pytanie o relację między administracją publiczną a partiami politycznymi.

Kwestia ta sięga swoimi korzeniami do okresu kampanii wyborczej (parlamentarnej, samorządowej, także prezydenckiej). Każda partia uczestnicząca w danej kampanii występuje z określonym programem mającym zgromadzić stosowny elektorat gwarantujący zwycięstwo wyborcze. Program jest z reguły odzwierciedleniem ideologii, światopoglądu, koncepcji gospodarczych i społecznych danej partii politycznej, a zatem wyrazem interesu tej właśnie grupy, proponowanym do akceptacji wyborcom. W wyborach uczestniczy co najmniej kilka partii politycznych, co oznacza, że żaden z poszczególnych programów, często istotnie różniących się w zasadniczych dla państwa i społeczeństwa kwestiach, nie ma charakteru powszechnego. Jest to podstawowa konstatacja, której, jak się zdaje, nie dostrzegają ugrupowania zwycięskie w danych wyborach. Daje się, niestety, zauważyć tendencja do prostego utożsamiania programu wyborczego, interesu grupowego z interesem publicznym. Tymczasem należy podkreślić, że zwycięstwo $\mathrm{w}$ wyborach, obojętnie na jakim poziomie (parlamentarnym, regionalnym, lokalnym), to nie prosta możliwość realizacji własnego programu, ale odpowiedzialność za państwo, region, powiat, gminę. Należy zatem podnieść potrzebę właściwego rozumienia interesu publicznego.

W ujęciu M. Stahl: „Najogólniej ujmując, publiczny to [...], powszechnie dostępny, do powszechnego użytku, to przeciwieństwo prywatnego, to coś przeznaczone do użytku zbiorowego, powszechnego"19. Podobnie wypowiada się M. Zimmermann: „Jest to więc interes dotyczący ogółu, nie będący jednak sumą interesów indywidualnych, ale stojący ponad nimi. Zawiera on wartości ogółu rozumianego integralnie, jednakże ogół ten jest wyodrębniony podmiotowo"20.

Zgadzając się z tymi poglądami, wypada jednak uzupełnić je postulatem o potrzebie wyraźnego odróżnienia terminu „,zbiorowy” także od terminu „grupowy”. Należy zatem jednoznacznie przeciwstawić się wszelkim przejawom utożsamiania interesu publicznego z interesem partyjnym (także z każdym innym grupowym). Ustalenie treści interesu publicznego nie może polegać na mechanicznym, bezrefleksyjnym przenoszeniu ideologii i programów partyjnych do treści ustaw. Interes publiczny to nie żadna „mantra”, żadne wygodne usprawiedliwienie wszelkich możliwych do wyobrażenia celów i sposobów ich realizacji. Materialne źró-

19 M. Stahl, Cele publiczne i zadania publiczne, [w:] Koncepcja systemu prawa administracyjnego. Zjazd Katedr Prawa Administracyjnego i Postepowania Administracyjnego. Zakopane 24-26 września 2006 r., red. J. Zimmermann, Warszawa 2007, s. 97.

20 M. Zimmermann, Aksjomaty prawa administracyjnego, Warszawa 2013, s. 94. 
dła interesu publicznego wynikają bowiem z wielu źródeł, poglądów, oczekiwań, opinii poszczególnych środowisk społecznych, parlamentarnych i pozaparlamentarnych ugrupowań opozycyjnych, upodmiotowionych społeczności lokalnych, organizacji zawodowych, kościołów i związków wyznaniowych, postulatów i ocen formułowanych w nauce, wniosków i skarg obywatelskich, krytyki prasowej (medialnej) — ogólnie — z wszystkich źródeł informujących o potrzebach, aspiracjach, nastrojach, postawach i ocenach społecznych. Partyjna proweniencja rządu, organów stanowiących i wykonawczych jednostek samorządu terytorialnego nie może prowadzić do realizacji wyłącznie własnych celów i interesów. W demokratycznym państwie prawnym administracja publiczna powinna być ,jak żona Cezara poza podejrzeniami”, neutralna ideologicznie, służąca państwu i społeczeństwu, dobru wspólnemu, nie zaś wyłącznie interesom formacji sprawującej władzę. Neutralność ideologiczna administracji publicznej nie wyklucza jej polityczności, jednakże rozumianej właściwie, to jest jako udziału w procesie ustalania celów i sposobów ich realizacji, przy zastosowaniu właściwie rozumianego interesu publicznego jako kryterium i celu polityki administracyjnej.

\section{KOŚCIOŁY I ZWIĄZKI WYZNANIOWE JAKO PODMIOTY ZBIOROWE OTOCZENIA ADMINISTRACJI PUBLICZNEJ}

Drugi z wyróżnionych szczególnych elementów kręgu zewnętrznego administracji publicznej to kościoły i związki wyznaniowe. Zgodnie z regulacją art. 25 Konstytucji podmioty te są równouprawnione. Władze publiczne Rzeczypospolitej Polskiej zachowują bezstronność w sprawach przekonań religijnych, światopoglądowych i filozoficznych, zapewniając swobodę ich wyrażania w życiu publicznym. Stosunki między państwem a kościołami i innymi związkami wyznaniowymi są kształtowane na zasadach poszanowania ich autonomii oraz wzajemnej niezależności każdego w swoim zakresie, jak też współdziałania dla dobra człowieka i dobra wspólnego. Konstytucja różnicuje jednak podstawy prawne stosunków między państwem a kościołami i związkami wyznaniowymi, wskazując, że odnośnie do Kościoła katolickiego są uregulowane umową międzynarodową zawartą ze Stolicą Apostolską i ustawami, w wypadku zaś pozostałych kościołów i związków wyznaniowych ustawami uchwalonymi na podstawie umów zawartych przez Radę Ministrów z ich właściwymi przedstawicielami. Pełna lista działających w Polsce kościołów i związków wyznaniowych zawiera następujące podmioty: Kościół katolicki, działający na podstawie konkordatu między Stolicą Apostolską i Rzecząpospolitą Polską ${ }^{21}$ i ustawy z dnia 17 maja 1989 roku o stosunku Państwa do Kościoła Katolickiego w Rzeczypospolitej Polskiej22; Polski

21 Dz.U. 1989 r. Nr 51, poz. 318.

22 Dz.U. z 2013 r. poz. 1169. 
Autokefaliczny Kościół Prawosławny, działający na podstawie ustawy z dnia 4 lipca 1991 roku o stosunku Państwa do Polskiego Autokefalicznego Kościoła Prawosławnego ${ }^{23}$; Kościół Ewangelicko-Augsburski, działający na podstawie ustawy z dnia 13 maja 1994 roku o stosunku Państwa do Kościoła Ewangelicko-Augsburskiego w Rzeczypospolitej Polskiej24; Kościół Ewangelicko-Reformowany, działający na podstawie ustawy z dnia 13 maja 1994 roku o stosunku Państwa do Kościoła Ewangelicko-Reformowanego w Rzeczypospolitej Polskiej25; Kościół Ewangelicko-Metodystyczny, działający na podstawie ustawy z dnia 30 czerwca 1995 roku o stosunku Państwa do Kościoła Ewangelicko-Metodystycznego w Rzeczypospolitej Polskiej26; Kościół polskokatolicki, działający na podstawie ustawy z dnia 30 czerwca 1995 roku o stosunku Państwa do Kościoła Polskokatolickiego w Rzeczypospolitej Polskiej 27 ; Kościół Adwentystów Dnia Siódmego, działający na podstawie ustawy z dnia 30 czerwca 1995 roku o stosunku Państwa do Kościoła Adwentystów Dnia Siódmego ${ }^{28}$; Kościół Chrześcijan Baptystów, działający na podstawie ustawy z dnia 30 czerwca 1995 roku o stosunku Państwa do Kościoła Chrześcijan Baptystów w Rzeczypospolitej Polskiej29; Kościół katolicki mariawitów, działający na podstawie ustawy z dnia 20 lutego 1997 roku o stosunku Państwa do Kościoła Mariawitów w Rzeczypospolitej Polskiej30; Kościół starokatolicki mariawitów, działający na podstawie ustawy z dnia 20 lutego 1997 roku o stosunku Państwa do Kościoła Starokatolickiego Mariawitów w Rzeczypospolitej Polskiej ${ }^{31}$; Kościół zielonoświątkowy, działający na podstawie ustawy z dnia 20 lutego 1997 roku o stosunku Państwa do Kościoła Zielonoświątkowego w Rzeczypospolitej Polskiej ${ }^{32}$.

Gminy wyznaniowe żydowskie, działające na podstawie ustawy z dnia 20 lutego 1997 roku o stosunku Państwa do gmin wyznaniowych żydowskich w Rzeczypospolitej Polskiej ${ }^{33}$.

Stosowne przepisy wskazanych umów i ustaw gwarantują kościołom i związkom wyznaniowym swobodę sprawowania kultu, prowadzenia działalności edukacyjnej, charytatywnej, katechetycznej, duszpasterskiej. Nie są jednak elementem formalnoprawnie włączonym w grupę podmiotów mogących oddziaływać na administrację publiczną, aczkolwiek takie oddziaływanie istnieje. Przybiera ono przede wszystkim formę postępowania zgodnego z danym światopoglądem wyra-

\footnotetext{
23 Dz.U. z 2014 r. poz. 1726.

${ }^{24}$ Dz.U. z 2015 r. poz. 43.

25 Dz.U. z 2015 r. poz. 483.

26 Dz.U. z 2014 r. poz. 1712.

27 Dz.U. z 2014 r. poz. 1599.

28 Dz.U. z 2014 r. poz. 1889.

29 Dz.U. z 2015 r. poz. 169.

30 Dz.U. z 2015 r. poz. 44.

31 Dz.U. z 2015 r. poz. 14.

32 Dz.U. z 2015 r. poz. 13.

33 Dz.U. z 2014 r. poz. 1798.
} 
żanym przez dany kościół czy związek wyznaniowy przez zatrudnionych i pełniących funkcje w administracji publicznej, a będących członkami danej wspólnoty religijnej oraz wyrażania stanowisk przez stosownych przedstawicieli władz danego kościoła czy związku wyznaniowego, aczkolwiek w jednym przypadku wpływ taki jest bardziej sformalizowany. Dotyczy to wyłącznie Kościoła katolickiego i przybiera postać działającej na podstawie art. 4 ustawy o stosunku państwa do tego Kościoła Komisji Wspólnej Rządu Rzeczypospolitej Polskiej i Konferencji Episkopatu Polski.

W kontekście możliwości wywierania wpływu przez kościoły i związki wyznaniowe na administrację publiczną należy wyraźnie wskazać, że i w tym przypadku, analogicznie jak w przypadku partii politycznych, administracja publiczna powinna się kierować przede wszystkim właściwie rozumianym interesem publicznym. Wyznawane treści światopoglądowe, stanowiska organów i przedstawicieli władz kościelnych i związków wyznaniowych, przy całym szacunku do nich, winny być traktowane jako co prawda ważne, ale tylko jako jedno z materialnych źródeł interesu publicznego. Administracja publiczna w demokratycznym państwie prawnym powinna być neutralna także światopoglądowo. Powinna wskazane jej zadania publiczne realizować, jak określał M. Weber, ,sine ira et studio, bez gniewu i namiętności, [...] pod presją prostego pojęcia obowiązku" ${ }^{34}$, ale jednocześnie w trosce o właściwie rozumiany interes publiczny.

\section{INSTITUTIONAL AND IDEOLOGICAL ENVIRONMENT OF PUBLIC ADMINISTRATION AND ITS SO-CALLED APOLITICISM}

Summary

Public administration is a special kind of organization. It functions in a specific environment. Political parties, Churches and religious organizations are its particular elements. Public administration should perform public tasks taking into account public interest. Public administration should be ideologically and world-view neutral.

Keywords: Public administration, organization, environment, public interest, political neutrality, world-view neutrality

\section{BIBLIOGRAFIA}

Griffin R.W., Podstawy zarzadzania organizacjami, Warszawa 1996.

Izdebski H., Kulesza M., Administracja publiczna. Zagadnienia ogólne, Warszawa 2004.

34 M. Weber, Gospodarka i społeczeństwo. Wstęp do socjologii rozumiejącej, Warszawa 2002, s. 168. 
Koźmiński A.K., Organizacja, [w:] Zarządzanie. Teoria i praktyka, red. A.K. Koźmiński, W. Piotrowski, Warszawa 2002.

Langrod J.S., Instytucje prawa administracyjnego. Zarys części ogólnej, Kraków 2003, (reprint).

Longchamps F., Założenia nauki administracji, Wrocław 1993.

Stahl M., Cele publiczne i zadania publiczne, [w:] Koncepcja systemu prawa administracyjnego. Zjazd Katedr Prawa Administracyjnego i Postępowania Administracyjnego, Zakopane 24-26 września 2006 r., red. J. Zimmermann, Warszawa 2007.

Steinmann H., Scheyogg G., Podstawy kierowania przedsiębiorstwem. Koncepcje, funkcje, przykłady, Wrocław 1992.

Stoner J.A.F., Freeman R.E., Gilbert D.R. jr., Kierowanie, Warszawa 2001.

Weber M., Gospodarka i spoteczeństwo. Wstęp do socjologii rozumiejącej, Warszawa 2002.

Zieleniewski J., Organizacja i zarządzanie, Warszawa 1981.

Zimmermann J., Aksjomaty prawa administracyjnego, Warszawa 2013. 